THE BOLLER REVIEW

\title{
A CRISIS OF FAITH, SCARY POPES, AND WILLIAM GLADSTONE
} JOSH JACKSON 
William Ewart Gladstone was a prominent, though controversial, figure in the history of Great Britain. While his career was in the realm of politics, Gladstone's influence on British history extended beyond the political atmosphere. Gladstone had lasting economic policies, an influence on the culture of Great Britain throughout the nineteenth century, and lastly, had a significant impact on the religious dimensions of Great Britain. Religion was one of the most important aspects of Gladstone's life, if not the most important. Primarily through analyzing his personal diaries, it is evident that this man could not say enough about religious matters. Correspondence with figures such as Lord Granville and Odo Russell also highlights Gladstone's thoughts on religion, particularly with the Roman Catholic Church. He was sure to insert his opinion on anything deemed remotely religious and was finely in tune with the various issues facing religion in Great Britain in the nineteenth century.

The backdrop for Gladstone's time in and out of office in Great Britain was the great Victorian "crisis of faith" that brought about several issues that citizens in the British Isles were required to address. The idea of Darwinism and other sciences were on the rise. Urbanization was rapidly occurring through the progress of the Industrial Revolution. The Anglican Church was forced to deal with people leaving the church for other traditions, or even becoming nonChristians. There was the issue of the development of new Christian movements, such as the Methodists and the ever-growing evangelical traditions. The Oxford Movement (also known as the Tractarian Movement), developed by E.B. Pusey, John Henry Newman, and others at Oxford University, gained traction across Great Britain. A significant problem that the British dealt with during the nineteenth century was the influence of the Catholic Church, especially through so-called "papal aggression" in 1851 when the Vatican restored the Catholic hierarchy in Great Britain. These issues created the setting in which Gladstone functioned in Great Britain. He grew up in this context, rose to power in this context, and ruled as Prime Minister in this context. Combining all of this, it is fairly logical that religion was so important to the famed William Ewart Gladstone.

As time went on, certain religious issues were more important to Gladstone. The most pressing topic for him was the Roman Catholic Church. It was regularly mentioned throughout his diaries, secondary sources highlighted his sentiments toward it, and the issues it presented during his tenure in office were ones that he needed to reconcile. Gladstone did not have a positive perception of the Roman Catholic Church, and this fueled anti-Catholic sentiments in Great Britain during this time period. His diaries have entire entries dedicated to his view on its aggression, and his various superstitions regarding the Roman Catholic Church. Gladstone's views on the Roman Catholic Church were primarily influenced by his own personal faith crises and the supposed papal aggression of 1851 and subsequent doctrines passed by the Roman Catholic Churchin the mid-to-late-nineteenth century.

Those Victorian Britons whose attitudes, ideas, and policies shaped public opinion on the Catholic Church during the mid-to late-nineteenth century generated anti-Catholic sentiment over the issues of papal aggression andthe Oxford Movement. Pusey, Newman, and others wrote a series of publications known as Tracts for the Timesthat called for reform of the Anglican Church. It was a common sentiment across Great Britain that the Oxford Movement promoted a closer institutional and theological relationship between Anglicanism and Roman Catholicism, and therefore it garnered much skepticism across the country. Gladstone was one of the more prominent Britons that had an influence on this problem of the Catholic Church.To understand Gladstone's own standpoint on the Roman Catholic Church, it is important to understand the general British public perception of it during this time period as well. Scholars have framed their research on this topic into several topics, including the papal aggression and the Oxford Movement.

The first of these causes is that British people generally held negative views of the Roman Catholic Church. This was especially highlighted throughout the era of the Victorian crisis of faith. A primary factor of the misunderstanding comes from none other than William Gladstone himself. He often argued that it did not function properly in Great Britain, that the religion manifested the destruction of civil rights, and even that the adherents of Catholicism had not even reached the developments of the Middle Ages. Josef L. Altholz emphasizes that Gladstone steadfastly opposed anything the Catholic Church did, but often times misconstrued it to appear as aggression from 
the church instead of the reform that it was intended to be. Altholz explains that Gladstone was angered by the doctrines the Catholic Church was establishing, such as the 1851 restoration of the Catholic hierarchy in Great Britain, a resolution that gave more structure to the British arm of the church. William Gladstone viewed the restoration as the Catholic Church attempting to take over Great Britain, even though the Catholic Church was reforming the structure it had in place in Great Britain. ${ }^{1}$ While Walter Ralls agrees, citing the so-called "papal aggression" of the Vatican's reinstatement of the Catholic hierarchy in Great Britain in 1851, Ralls reviewed British reactions to this episode and discovered "renewed insistence on the old charge that Catholicism was incompatible with English political institutions as it was led by one figure, the Pope, who was not a part of the Church of England or the government of England." 2

A second school of thought regarding the root of the British opinion of the Catholic Church during the Victorian crisis of faith was the Oxford movement and the general response to it. For instance, one satirical cartoon shows Pusey, the Oxford professor who developed the movement, as a fly that is flying dangerously close to a Roman candle (representing the Catholic Church). ${ }^{3}$ This cartoon exhibits that British people associated the Oxford movement with the Catholic Church, influencing what they thought of the Catholic Church. Another scholar, C. Brad Faught, argues that Britons believed that the Oxford Movement and its attempts to influence the Church of England functioned dangerously similarly to the Roman Catholic Church. ${ }^{4}$ This movement was viewed as dangerous for Great Britain, particularly by Gladstone himself, because some believed that it would ultimately lead to the reunification of the Church of England with the Church of Rome and would thereby restore formal Roman Catholic reign over Great Britain.

Finally, British perceptions of Ireland also shaped British opinion on the Catholic Church. Altholz places Gladstone in this context by explaining that he had to be mindful of his policies toward Ireland, such as exempting it from the Anglican Church tax, as he did not want to appear to be benefitting the church that many Irish adhere to, the Catholic Church. ${ }^{5}$ Ireland was also a common factor that Black and MacRaild also mentioned in their research. The predominant conclusion that was drawn from the influence of the Irish on the British perception of the Catholic Church was the negative opinion of the Irish people, who were mainly Catholic, often times translated over to a negative opinion of the Catholic Church. It appeared that the Catholic Church was negative by association with the Irish, especially as a result of political and civil unrest inlreland during this time period.

In conclusion, it is evident that there were a multitude of factors that contributed to the British public opinion of the Roman Catholic Church during the era of the Victorian crisis of faith. However, while some scholars focused on the influence of the Oxford movement during this timeperiod, others emphasized reactions toward the Vatican that led to anti-Catholic sentiments in Great Britain. Overall, this lays the framework for researching these two factors in conjunction with one another. The most convincing part of the previous scholarship for my research is the influence of the papal aggression on the perception of the Catholic Church in Great Britain. The Oxford Movement appears to be a component of the fear of papal aggression; however, the Oxford Movement did predate the papal aggression itself. Therefore, it would have been the legacy of this movement that influenced the British perception of the Roman Catholic Church. From here, I will be researching William Gladstone and how his perception of the Roman Catholic Church was formed. I will include research on the papal aggression, and William Gladstone's personal crises and crises of faith worked together to create his highly negative perception of the Roman Catholic Church. The new scholarly direction that I will be taking with this is studying the influence that Gladstone's own personal faith and his personal crises in conjunction with the papal aggression and other prominent decrees by the Vatican had on his perception of the Roman Catholic Church.

William Ewart Gladstone was born in Liverpool on 29 December 1809 to Sir John Gladstone and his second wife, Anne Robertson. The Gladstone family was a wealthy family that gained income through the corn and tobacco trade and through their slave-run sugar plantations in the West Indies. Religion held a prominent position in Gladstone's life right from the onset. He was born into an evangelical family that joined the Church of England upon moving to Liverpool. Gladstone was baptized into the Anglican Church at St. Peter's Church in Liverpool and his 
Anglican faith remained with him from the beginning of his life until the end. Prior to Gladstone's arrival at Eton in 1821 to join his brother Thomas, William attended a small school in nearby Bootle run by an evangelical, William Rawson. At Eton, Gladstone discovered a skill for public speaking through the Eton Society. He also published the Eton Miscellany in 1827 with George Selwyn, who would later become a prominent bishop. While Gladstone did do well at Eton, he kept his passionate religious practice to himself. He maintained his evangelical religion despite his dislike for the type of religious atmosphere at Eton. It was also during his time at Eton that Gladstone began to form his opinion and thoughts regarding the Roman Catholic Church. From that point forward, Gladstone began to rise in the British public sphere and began to work his way into the realm of politics. ${ }^{6}$

William Gladstone's passion for religion pervaded most, if not all, aspects of his life. His views on religion were a primary component of his lengthy career in politics. His personal faith is what informed this from an insider perspective. The clearest insight into his own personal faith and the issues that he had that were associated with it can clearly be located in his own personal diaries, The Gladstone Diaries. Gladstone wrote extensively about topics pertaining to religion. These writings ranged from church polity and structure, feelings about the Catholic Church, the Oxford Movement, and of course, feelings and issues pertaining to his own personal faith. Each of these issues, and more, contributed to Gladstone's zeal for religion, but his own personal faith can be most closely examined through these diaries.

One of the most notable entries in Gladstone's diary comes from Thursday, 1 February 1827. Gladstone writes about his confirmation within the Church of England. This particular entry is unique in that it is not just a reflection on a typical Sunday worship experience or sermon that Gladstone found moving. The entry displays clearly William Gladstone's personal feelings on such a significant experience within the Church of England. The entry takes the form of a fiery, passionate prayer to God on the day of his confirmation. A common theme throughout is Gladstone's ownfeeling of brokenness and how he was "most unworthy of so great a privilege." The prayer begins by William Gladstone invoking God to "look down in mercy on thy sinful creature" (referencing Gladstone himself), so that he may "go forth strengthened by Thy Holy Spirit" into the world. In this prayer, Gladstone is praying to God to allow him to do God's work correctly in the world, all while requesting that God purify his thoughts, words, and deeds. Clearly, Gladstone was experiencing a major faith crisis at this time as he is continually referring to how horrible of a person he is. Interestingly enough, the diary entries preceding this one do not discuss something terrible he had believed he had done; they are all centered around his biblical readings and studying of various theologians and other religious figures. Potentially, the act of going through such an important ritual in the church could have brought this faith crisis upon Gladstone as the Victorian church, especially evangelicalism, did place a significant emphasis on guilt. Gladstone believed that he was a guilty, sinful man that needed God's guidance to do God's work in the world. At the end of the prayer, Gladstone shifts the discussion from himself to other people. He prays specifically for the two hundred other people that were confirmed that day alongside him. He asks that God guard them from temptation, guide them away from what is evil, and to excite them in virtue, strengthen them in faith, confirm them in penitence, and to lead them to the "mansions which are prepared for those who are washed in the blood of the Lamb." The message of guilt and need for God's grace continued even in his prayer for other people. The last line possibly reveals why Gladstone was praying on all of these topics, he requests that God guide them to heaven. He was probably not telling God to take them to Heaven right then, but to show them the path that he believed that God wanted them to take in order to get to heaven. That part of the prayer highlights Gladstone's views on the afterlife, for he evidently only believed that certain people would make it to heaven upon their death. Gladstone's personal religion appeared to have been one based out of fear of punishment from God. That fear contributed to William Gladstone's passion for religion. He might have believed if he was not passionate and did not care about religion, then he could have a quite unfortunate fate awaiting him when his time on earth draws to a close. ${ }^{7}$ Gladstone continues his church attendance through the years following his confirmation, and he often noted his thoughts on worship services he experienced or sermons he heard throughout his diaries. 
Gladstone was a regular church attendee, and often had thoughts and feelings about what he had experienced in worship that day. On Monday, 3 September 1838, there is a lengthy diary entry that reflects on a sermon that he had heard at the "R.C. Church" the previous morning. The church, though unnamed, is possibly a Lutheran Church as the end of the diary entry contains a brief discussion about the Lutheran prayers and items found within the church. This diary entry begins with William Gladstone's basic summarization of the priest's sermon. This starts out by his acknowledgment that he "caught his words most imperfectly," meaning he knows that he did not pay complete attention the entire time and therefore did not catch every aspect of the sermon. The entry provides a glance into William Gladstone's own personal theology. Gladstone "was favourably impressed by" Miller's (the priest's) evangelical sermon about how humankind was shut out of the doors of Heaven because of sin, and even though "the precious blood of Christ was the key"to open the doors back up, "men remained cold and unthankful." The reflection on the early church continues with the earliest apostles such as St. Peter and St. Paul, and how they "were to live to God, to do all things to his glory" as they were supposedly called to do. Within this early church segment of the sermon, Gladstone notes that Miller spoke on how the "pious forefathers" of the church "flocked daily to the House of God" to be in union with God and God's mission for them, but how now only "few answered to the call of the daily bell" (referencing the church bells that would call people to services at the church during this time in Great Britain). The sermon that Gladstone wrote about here is indicative of what was occurring in the wider church in Great Britain during the nineteenth century. This diary entry in general reflects the growing crisis of faith that was occurring in Victorian-era Britain. It clearly demonstrates the problem that William Gladstone had with people not being as pious and loyal to the church as they had been in decades past. The last point from the sermon that William Gladstone included in this diary entry, after his discussion of the sermon that he had heard the day before, William Gladstone then reflected on his time at the church itself, and the time right after. He noted that it was crowded, but with people that he deemed to be "poorer" from the garments they were wearing. He also mentioned that the Russian Prince was also in the church service but did not arrive until after the sermon had reached its conclusion. He also notes that that the "gaming table" for gambling was already open during the time of worship, and how he "saw shops open at half past eleven." These three matters were clearly a problem for him as he writes the rhetorical question, "Is God then no longer a jealous God?" It was evidently unsettling for William Gladstone to see these non-sectarian establishments open and functioning during the time that William Gladstone so clearly believed were to be dedicated to the worship of God. ${ }^{8}$ The entry does not directly relate to the Roman Catholic Church; however it provides a background insight into William Gladstone's personal theology that influenced his perception of the Roman Catholic Church.

Before the papal aggression of 1851, William Gladstone did not write extensively about the Roman Catholic Church from a negative standpoint. Prior to this reinstatement of the Catholic hierarchy in Great Britain, Gladstone's perception of the Roman Catholic Church was surrounded by superstition. Gladstone's superstition was first seen in an entry from 11 November 1838. At the time of this entry, Gladstone was visiting Italy. In this entry, he writes about his long day of travel and describes what he sees. In two brief moments in it though, slight disdain toward the Roman Catholic Church can be seen. A companion Gladstone had on this day was Monsignore Rossi, a criminal judge in Rome. Gladstone wrote that at one point in the day Monsignore "was very anxious to stop and hear mass" because it "discharged their obbligo (obligation)." "The meaning behind Gladstone's writing here could be that he feels Monsignore felt obligated to attend Catholic Mass, and that was causing Monsignore a great deal of anxiety. Gladstone did not speak of this positively, he clearly viewed this from a more negative standpoint about the practices of the Roman Catholic Church. He potentially could have felt that the Roman Catholic Church was coercing its adherents into attending Mass, leading to Monsignore's feeling of obligation to it. This entry provided a minimal glance into Gladstone's views of the Roman Catholic Church, but an entry from four years later displays a more negative opinion of the Roman Catholic Church.

In an entry from 31 July 1842, the first truly negative perception of the Roman Catholic Church is documented. William Gladstone describes his day, as usual, but it begins with his thought regarding a discussion he had with R. Williams about the Irish Church (the Catholic Church in Ireland) and the Oxford Movement. Not only does this show 
a negative view of the Roman Catholic Church, but it also shows that Gladstone did directly connect the Roman Catholic Church to the Oxford Movement. This entry is an inflammatory discussion of these topics. He describes that "it is startling" how the "Oxford writers and their friends" not only appear to seek "the renewal and development of the Catholic idea within the pale of the Church of England" but that they also "consider the main condition of that development and of all health to be reunion with the Church of Rome." Gladstone articulated his belief that the Oxford Movement is a direct attempt to reconnect the Anglican Church to the Roman Catholic Church. The idea is superstitious, but Gladstone continues. Gladstone argues here that "they" (the Oxford writers) are "Catholicising the mind of the members of the Church of England." This entry is riddled with a tone of superstition and paranoia. Gladstone believed that "they have no strong feeling of revulsion from actual evils in the Church of Rome." That statement shows his superstition extended beyond the Oxford/Tractarian Movement to the Roman Catholic Church itself. He does not explicitly mention what those evils are, just that there are evils in the Church of Rome. Gladstone bases this argument on Tract 90. Tract 90 was written by John Henry Newman, an Anglican priest and associate of William Gladstone. Newman converted to Catholicism in 1845, which was not received well by Gladstone. This tract was written prior to the conversion of Manning, though. The main theme of Tract 90 is an analysis of the 39 Articles, a component of the Anglican Church that is often thought to have been directed against the Roman Catholic Church. However, in Tract 90, Newman argues that these articles were actually directed against popular errors and exaggerations regarding the Roman Catholic Church. In this tract, Newman discusses how the 39 Articles "are evidently framed on the principle of leaving open large questions" and "they state broadly extreme truths" while staying silent about how they arrived at those truths. The entire tract counters what the 39 Articles are saying and corrects it with what the Roman Catholic Church actually believes. ${ }^{10}$ It is evident from Gladstone's diary entry from 31 July 1842 that he believed Tract 90 defended the Roman Catholic Church, including its "evils." Gladstone would have perceived Tract 90 as an explicit defense of the Roman Catholic Church. The overall theme of this entry is that Gladstone is whole-heartedly convinced that the Oxford Movement is essentially a rogue agent in Great Britain seeking to reunite the Anglican Church with the Roman Catholic Church. It is highly superstitious, and the tone reveals a significant amount of stress felt by Gladstone regarding this issue. He ends the entry by writing that "all this is matter for serious consideration: in the meantime I was anxious to put it down while fresh." Gladstone wanted to continue to reflect on this perceived problem and felt the need to write that he was anxious about recording it. ${ }^{11}$ While Tract 90 was written by Newman, prior to his conversion, in order to correct misconceptions and incorrect opinions about the Roman Catholic Church, Gladstone viewed Tract 90 as an unapologetic defense of the Roman Catholic Church, further solidifying his paranoid idea that the Oxford Movement worked directly for the Roman Catholic Church. Moving through Gladstone's diary entries chronologically illuminates the development of his perception of the Roman Catholic Church. It was never positive or complimentary, but it transitioned over time from mildly disliking the Catholic Church, to the superstition seen between the 1838 and 1842 entries, to finally a truly negative perception of it that began in 1851 at the time that the supposed "papal aggression" came into fruition.

The turning point for William Gladstone's perception of the Roman Catholic Church occurred in 1851 when the "papal aggression" occurred. The idea of a papal aggression came directly from the Pope's reinstallation of the Catholic hierarchy in Great Britain. Gladstone first mentioned the papal aggression in his diaries in an entry on 10 February 1851 during his visit to Naples, Italy. It is a short entry that describes how Gladstone met with a Cardinal in the Roman Catholic Church about the papal aggression. Gladstone remarks that the Cardinal "did not see any lesion of territorial rights and did not like the exequatur (a right of temporal authorization for papal exercise of episcopal functions)." Gladstone then met with P. San Giacomo about the intentions of the Italian government, and he was "dissuaded by him for fear of making matters worse." ${ }^{12}$ Gladstone is apparently displeased with the Cardinal's response, as it has a tone of disagreement with it. Here, Gladstone is evidently highly bothered by the restoration of the Catholic hierarchy in Great Britain to the point of inquiring about the Italian government's intentions at the time. Gladstone's negative views on the Italian government itself, which was closely associated with the Roman Catholic Church at the time, can be seen throughout the remainder of his diary entries from this particular visit to Italy. In the 
13 February 1851 entry, Gladstone visited an Italian, Poerio, who was incarcerated in a prison on the fortress on Nisida Island, just southwest of Naples. Gladstone wrote that Poerio believed the Italian government was corrupt and unable to be a true republic and that he admired the English government and its successes-two points to which Gladstone agreed. In the context of the other entries, specifically the ones about the papal aggression, Gladstone's negative perception of the Roman Catholic Church could also be associated with a negative view of the Italian government, but it could also function the other way as well. The two go hand-in-hand, and Gladstone would not have wanted that for Great Britain. Gladstone compared the corrupt Italian government and the Roman Catholic Church by extension of the government, to the Conservative Party in Great Britain. ${ }^{13}$ His comparison is significant because he believed the Conservative Party was corrupt, he mentions that in this diary entry as well, and then translates this idea of corruption over to the Roman Catholic Church. He extends his idea of corruption from the Vatican to the Italian government in general, as Gladstone believed that the Italian government functioned as a component of the Roman Catholic Church. It was already known that Gladstone did not like the Conservatives, and his associating them with the Italians functions to show his dislike for the predominantly-Catholic Italians. This could all be a result of the papal aggression. Gladstone brings up the papal aggression again soon after this prison visit, as well.

William Gladstone concluded this trip to Italy on 25 February 1851 when he arrived in Paris, and finally back to London on 26 February 1851. Upon his return to London, Gladstone again wrote more about the issue of the papal aggression. ${ }^{14} \mathrm{He}$ wrote about it as a serious issue that Great Britain needed to face, as it was challenging to the British way of life in that its practices and beliefs were incompatible with the current Anglican Church's influence. Gladstone believed that the Roman Catholic Church was incompatible with the structure of Great Britain and the Anglican Church because it was a challenge to his authority in Great Britain. The papal aggression, to Gladstone at least, appeared to be an attempt by the Roman Catholic Church to reinstall its authority in Great Britain. Gladstone did not want the Roman Catholic Church to have any form of religious jurisdiction in Great Britain, as that could be a threat to his sovereignty. Now, Gladstone's polemical attitude toward the Roman Catholic Church truly begun to take shape. Combining his background of faith crises and other personal issues with his response and sentiments toward the papal aggression, Gladstone's negative perception of the Roman Catholic Church came to life.

An important event in British history that occurred in 1851 that had a direct impact on William Gladstone was the conversion of Henry Edward Manning to Catholicism. Throughout Gladstone's diaries, Manning is mentioned in a positive manner prior to the conversion. Gladstone regarded Manning as a prominent theologian and figure within the Anglican Church. However, that changed in 1851. Manning converted to Catholicism, and eventually became a priest and worked his way up to be the Archbishop of Westminster in 1865. This conversion shocked Gladstone. On 6 March 1851, Gladstone wrote on the beginnings of the conversion. He apparently "argued for two hours" with Manning about it because "Manning's mind is made up" about the conversion. ${ }^{15}$ On 9 March 1851, just three days later, Gladstone wrote that he met with Manning for three hours to try and persuade him to not convert, which was unsuccessful. ${ }^{16}$ On 5 and 6 April 1851, the actual conversion is written about. In the entry from April 5, Gladstone wrote that "the blow is falling tomorrow," and then the next day wrote that this day was "a day of pain!"17 On 7 April 1851, the day after the conversion, Gladstone's vulnerable entry highlights just how crushed he felt about Manning's conversion to Catholicism. He wrote that his "hope too is gone" because of the conversion and that "these dismal events have smitten" him. The surrounding entries also have a fairly dismal tone. ${ }^{18}$ Manning's conversion to Catholicism shook Gladstone to the core, and Gladstone did not write positively of Manning again after this conversion. At the same time this conversion happened, the papal aggression was occurring. The occurrence of this conversion at the same time as the papal aggression would not have helped Gladstone's perceptions of the Roman Catholic Church. The year 1851 was transformative in Gladstone's opinion of the Roman Catholic Church, it only worsened from there.

Gladstone's diaries from 1851 forward have multiple entries consisting of negative remarks regarding the Roman Catholic Church. Some of these entries are simply comments about how he disagrees with Catholics, as seen in his discussion of baptism in the Monsignore diary entry. Others have notably harsher comments about the Roman Catholic Church. One of the more polemical entries is from 24 December 1869, Christmas Eve. In this entry, Gladstone 
is not having a very happy Christmas. The second part of the entry is a response to a letter to Lord Clarendon, the Foreign Secretary in the British government at the time. Gladstone has a numbered list of three statements, which are most likely responses to three issues that Lord Clarendon posed to him in the original letter. The first two discuss political and financial issues that Gladstone was needing to reconcile, but the third one was a direct attack on Catholics. Gladstone says that he is "sorry to be too well prepared to concur in Odo Russell's anticipation" but his one reservation is that he believes "the papalists are not going backwards to the Middle ages" but that he wishes "they would go forward to the Middle Ages." Gladstone leaves no explanation as to why he feels that the Catholics are behind even the Middle Ages, simply that he feels that way. It is not written in this letter or diary entry specifically, but at this time the Roman Catholic Church was discussing the idea of papal infallibility, meaning the Pope had the final say on everything and was completely correct in his opinions. The discussion of this topic gained traction in the latter-half of 1869, but truly took hold in the Roman Catholic Church in 1870. The original letter itself from Lord Clarendon is not recorded, but he was agreeing with some proposition from Odo Russell, the ambassador to Germany for Great Britain, except that he believed the Catholics need to go forward to the Middle Ages. Interestingly enough, in this same diary entry there is another letter that has a different religious problem that Gladstone was facing. In a letter to Earl Spencer, an Irish lord lieutenant, Gladstone wrote that "Abercorn's speech is a greater offence than many a crime for which his fellow country men have had to answer." He includes a personal attack on Abercorn, by asking "what can you expect from a dandy of 55 turning statesmen?" While it is common for Gladstone to use personal attacks such as this in his diaries, it is significant for this one as this attack derives from a religious issue. This crime that Abercorn committed, it turns out, was a Protestant-led demonstration against William Gladstone and his policies toward Ireland. It is not clearly written in the entry what the protest was about, nor is the Belfast Morning Newsarticle accessible, but the Irish were not pleased with Gladstone. At the same time that Gladstone was dealing with his problem with the Roman Catholic Church, he now had members of his own faith tradition protesting against him. The group of protesters were Irish, as this was recorded in the Belfast Morning News on 10 December 1869 per the diary, but nevertheless it was fueling Gladstone's developing personal crisis. Combining this with his pre-conceived anti-Catholic sentiments creates a unique religious dimension for William Gladstone. ${ }^{19}$

The 1870s is a time period where a considerable amount of negative comments made by William Gladstone regarding the Roman Catholic Church can be found. At the very beginning of the 1870s, the Pope passed the Vatican Decrees. In 1869, the topic of papal infallibility was widely-known. It was a controversial topic that essentially stated that the Pope was never wrong and what he said goes. It was commonly assumed that this very topic was to be discussed at the General Council of the Roman Catholic Church in that year. Gladstone was unsurprisingly concerned about this. He believed that by establishing this doctrine, Pope Pius IX would be able to commit the Roman Catholic Church to his politics, which could threaten Gladstone's sovereignty in Great Britain. It was known that Gladstone viewed the Roman Catholic Church as aggressive at this point in history, especially by analyzing his responses to the papal aggression in 1851. Gladstone thought that the doctrine of papal infallibility would mark the success of the Roman Catholic Church as an "anti-social force" that would hinder the Anglican Church and his rule in Great Britain. ${ }^{20}$

Prior to the convening of the General Council of the Roman Catholic Church, Gladstone requested that Lord John Acton, a close associate of Gladstone's, publicize Gladstone's views on the doctrine of papal infallibility-that he disagreed with it entirely. Acton was instructed by Gladstone to "use the strongest language" possible to spread Gladstone's opinion on this topic. This occurred at the same time that other state leaders expressed their state's concerns with the idea of papal infallibility, including Bavaria. However, the members of the Roman Catholic Church pushing for the accepting of this dogma prevailed and the doctrine of papal infallibility was passed in the Vatican Decrees of July 1870. The concept became accepted throughout the general Roman Catholic Church, including in Great Britain. Upon its passing, much of the opposition dissolved except for William Gladstone. ${ }^{21}$ However, Gladstone would not speak publicly on this issue until 1874.

Further complicating the situation for Gladstone, one of the most fervent supporters of the dogma of papal infallibility was the Catholic Archbishop in Great Britain, Henry Edward Manning. Manning's conversion to Catholicism 
in 1851 had already significantly impacted Gladstone. The conversion not only hurt Gladstone personally, but it also further deteriorated his opinion of the Roman Catholic Church. Manning's support of papal infallibility appeared to have exacerbated Gladstone's sentiments regarding this new doctrine. Manning and his Roman Catholic faction in Great Britain were among those who favored the most extreme interpretation of papal infallibility so that it maximized the authority of the Roman Catholic Church. Archbishop Manning argued that the doctrine of papal infallibility extended to the relationship between the Church and the State. For Manning specifically, this meant the state of Great Britain. Manning believed that the restoration of states to the Roman Catholic Church would solidify the authoritative position of the Pope within global society and that Roman Catholics as a whole needed to support this, including British Catholics. ${ }^{22}$ This would not have been received well by Gladstone. He now had a former close associate and friend of his directly calling for the holistic restoration of the Roman Catholic Church's religious and political authority in Great Britain, explicitly threatening Gladstone's position as Prime Minister and his authority in the British government. With that background of the 1870s beginning with such a bold step by the Roman Catholic Church that William Gladstone viewed so negatively, a decade of new attacks and polemical comments on the Roman Catholic Church by Gladstone opened up. The 1870s was riddled with aggressive commentary on the Roman Catholic Church by Gladstone, but several of them are more distinct than others. One notable attack on the Roman Catholic Church that reveals Gladstone's negative perception of it can be seen in his diary entry from 28 February 1872. This specific one is in a letter to H.A. Bruce, home secretary. The brief letter is solely about the Roman Catholic Church, specifically in Great Britain. He writes to Bruce that he saw in "the Morning Post that two addresses are about to be presented to the Queen and Prince of Wales respectively... from the Catholic Archbishops of England." Gladstone did not elaborate as to why the Catholic Archbishops in England were addressing the Queen and the Prince of Wales. From the surrounding diary entries and the footnotes from Foot's edition, it appears that the meetings were about the state of the Roman Catholic Church in Great Britain. Gladstone believed that this event was "no accident but a purpose," mirroring his earlier superstitious beliefs about the Roman Catholic Church as seen in earlier diary entries, and that it was "a part of the system of aggression." Twenty years after the papal aggression, Gladstone is now asserting that the Roman Catholic Church in general is "a system of aggression." Gladstone believes that the British "government should steadily withhold its countenance" from the Roman Catholic Church in order to stop its advances. The letter then concludes, with no response from Bruce. ${ }^{23}$ It appears that Gladstone viewed these presentations, which are not described, to the Queen and then the Prince of Wales as acts of aggression originating from a larger system of aggression, the Roman Catholic Church. Gladstone was blatantly anti-Catholic at this time in his life.

Gladstone's anti-Catholic sentiments even pervaded seemingly minor aspects of his life. On 17 December 1873, a typical short entry that just listed what he did that day is written. After listening to Mr. Walsham How, canon of St. Asaph and Bishop of Wakefield, preach a sermon and after writing several letters, Gladstone finished reading Life of Montalembert. The only comments in this precise diary entry are that Gladstone enjoyed the book because it was about a "pure and noble career" but that "the Pope was a worm in the gourd all through." 24 Simply the Pope's presence in a book was irritating enough for Gladstone to describe him with a degrading metaphor. Any aspect of Catholicism, even in a book, was viewed in a negative light by Gladstone.

On 3 March 1874, another letter involving Odo Russell, the British Ambassador to Germany, is documented in William Gladstone's diaries. The main focus of this letter is that Gladstone believed "the people of this country have condemned us (him and his associates." He was currently in the final stages of his first official premiership during the time that he wrote this letter to Russell. In the midst of his discussing this downfall that he believes has unfairly come upon him, he mentions that the new ministers essentially do not care about "Church \& State." That would have greatly upset the ever-religious Gladstone. In his continuing rant, Gladstone moves on to point out to Russell that "Bismarck's ideas and methods are not ours: they spring out of another tradition but my sympathies though they do not go with him (and they are not worth a straw are more with him than against them." It is quickly revealed that these ideas and methods are fromthe Roman Catholic Church as in the very next sentence Gladstone writes that he "cannot but say that the present doctrines of the Roman Church destroy the title of her obedient members to the enjoyment of civil 
rights." He frames this polemic against the Roman Catholic Church specifically in the context of Great Britain when he tells Russell that he "in this country I [Gladstone] should object to any infringement of them." Gladstone has taken his argument against the Roman Catholic Church to be posed toward its doctrines, he argued that the Roman Catholic Church destroys the civil rights of its members through its doctrines. He argued this potentially because of the Vatican Decree about papal infallibility, as that would have reduced the importance of each Catholic individual's thoughts if the Pope had a statement about any particular topic. While the implication here is clear, Gladstone also believes that if the Roman Catholic Church continued to hold a presence within Great Britain, it would infringe upon the civil rights of the Britons and Gladstone would not allow that. As strong of a stance as this may be toward the Roman Catholic Church, Gladstone did not want to make this public knowledge. He concludes the letter by writing "I should hate to say this publicly, for I want no more storms; but it may become necessary." At this time in Gladstone's illustrious career, he was facing his first initial downfall from his tenure as prime minister. His rival, Benjamin Disraeli, had just recently been elected to the premiership and left Gladstone to reflect on what to do next. Gladstone already faced a significant amount of these "storms" in the recent time, which could explain why he was hesitant to bring this new opinion of the Roman Catholic Church to the British general public. At the time that this letter was written, Gladstone was experiencing his personal crisis of losing the premiership.

The year 1874 was a rough year for William Gladstone. He formally resigned from the position of Prime Minister following his tremendous loss in this election alongside his Liberal Party, and then he watched his rival, Benjamin Disraeli, ascend to the premiership. The loss of this election rocked Gladstone, and the success of Disraeli and his Conservative Party further worsened Gladstone's personal state. It is at this time that Gladstone himself publicly spoke out about the Vatican Decree of papal infallibility for the first time. Prior to this, he spoke about it through the channels of other people in his life, such as Lord John Acton in 1869 and 1870. Gladstone asserted he remained silent on the topic for the public's sake and so that it would not taint the opinion on his policies toward Ireland. He explained that it would have been difficult for him to pass policies for the predominantly-Catholic Ireland if he had spoken out negatively against their church as that potentially would have shifted public and governmental opinion to be negative toward Ireland. However, his view that papal infallibility was wrong and dangerous for society had existed since the doctrine was first discussed. Similar to mentioning the Pope or the Roman Catholic Church in seemingly random instances, such as the "worm in the gourd" analogy from 17 December 1873, Gladstone now mentioned the Vatican Decrees in a similar manner. In a publication Gladstone wrote following the passing of a bill against "ritualism" in the church, he expressed his thoughts as to why this bill was horrible. Within it, he writes that "Rome has a policy of violence and change in faith" and that "she has refurbished, and paraded anew, every rusty tool she was fondly thought to have disused." Here, Gladstone alluded to the Vatican Decrees and specifically the doctrine of papal infallibility. ${ }^{25}$ The old tool made anew was the doctrine of papal infallibility. In light of his earlier comments on the Roman Catholic Church being in the Middle Ages, some of his reasoning for that opinion is clear because of this passage. He wrote that the comment about the Roman Catholic Church needing to move forward to the Middle Ages on 24 December 1869. This occurred at the exact time that the doctrine of papal infallibility was being discussed throughout the Roman Catholic Church. The accepting of the idea that the Pope was right in every aspect, including in politics, by the Roman Catholic Church was a significant influence on Gladstone's opinion of the Roman Catholic Church. It only furthered his ideas that stemmed from the papal aggression of 1851 that the Roman Catholic Church was "a system of aggression" that sought to reassert its control over Great Britain. Expressing these negative feelings about the Roman Catholic Church coincided with the crises that evolved in Gladstone's life in the late-nineteenth century. 1851, the same year as the papal aggression, marked the conversion of Henry Edward Manning to Catholicism. 1874, the year Gladstone's first term as Prime Minister came crashing to an end, is when Gladstone first publicly spoke out about the teaching of papal infallibility. The feelings had been present, but he did not make them known from his mouth until this crisis of losing the premiership occurred. The ongoing relationship between Gladstone's personal problems and the passing of decrees and doctrines by the Roman Catholic Church created his negative opinion of the Roman Catholic Church, especially in the latter-half of the nineteenth century. 
William Gladstone's time in office, and life in general, was filled with various personal crises that translated over into his faith, such as his work with prostitutes that then caused him to whip himself out of guilt. He had times where he struggled with religion in Great Britain throughout the Victorian crisis of faith, as he believed that the British society was becoming increasingly less pious. His Anglican faith influenced most of what he did throughout his life, and his time as prime minister was no exception to this. All at the same time that Gladstone had his own problems that he needed to reconcile, the Roman Catholic Church was also working through a number of conditions.

Gladstone had an interest in the Roman Catholic Church beginning with his time at Eton, and it developed into outspoken dislike of the faith tradition by the time of the papal aggression in 1851. Combining his personal issues with the Roman Catholic Church's restoration of the papal hierarchy in Great Britain in the midst of the Victorian crisis of faith, Gladstone developed a highly negative perception of the Roman Catholic Church. It evolved from mild superstitions about their worship practices, such as baptism, to blatantly labeling it as a system of aggression that destroys the civil rights of its adherents.

The combination of William Gladstone's personal crisis with the redeveloping Roman Catholic Church throughout Europe, and particularly Great Britain, is what caused Gladstone to hold the Roman Catholic Church in such a negative viewpoint. Many of the diary entries that Gladstone wrote that are hostile toward the Roman Catholic Church coincide with some other personal problem that Gladstone was dealing with at the time, such as the conversions of Newman and Manning to Catholicism and then his loss of the premiership in 1874. His polemical nature toward the Roman Catholic Church in turn disseminated throughout the greater population of Great Britain, fueling anti-Catholic sentiments throughout the country during its Victorian crisis of faith. William Gladstone himself did not change this viewpoint, at least as seen in his diaries, for the remainder of his life. 


\section{Endnotes}

1Josef L. Altholz, "Gladstone and the Vatican Decrees," The Historian 25, no. 3 (1963): 312-324, http://www.jstor.org/ stable/24441526.

2Walter Ralls, "The Papal Aggression of 1850: A Study in Victorian Anti-Catholicism," Church History 43, no. 2 (1974): 242-256. DOI: 10.2307/3163955, http://www.jstor.org/stable/3163955

${ }^{3}$ Jeremy Black and Donald M. Macraild, Nineteenth-Century Britain (New York, NY: Palgrave MacMillan, 2003).

${ }^{4} \mathrm{C}$. Brad Faught, "Disraeli and Gladstone in the 1840s: The Influence of the Oxford Movement on Young England and the Board of Trade, The Canadian Society of Church History,

https://churchhistcan.files.wordpress.com/2013/06/1995-4-faught-article.pdf

${ }^{5}$ Altholz, "Gladstone and the Vatican Decrees."

${ }^{6}$ H. C. G. Matthew, "Gladstone, William Ewart," Oxford Dictionary of National Biography, (23 September 2004), https:// doi-org.ezproxy.tcu.edu/10.1093/ref:odnb/10787.

7William Gladstone, The Gladstone Diaries, 1825-1832, ed. M.R.D. Foot (Oxford: Clarendon Press, 1968$), 97$.

${ }^{8}$ William Gladstone, The Gladstone Diaries, 1833-1839, ed. M.R.D. Foot (Oxford: Clarendon Press, 1968$), 398$.

Ilbid., 499-502.

${ }^{10} \mathrm{John}$ Henry Newman, Tract 90, 1841, Project Canterbury, http://anglicanhistory.org/tracts/tract90/fulltext.html.

${ }^{11}$ William Gladstone, The Gladstone Diaries, 1840-1847, ed. M.R.D. Foot (Oxford: Clarendon Press, 1968$), 216$.

${ }^{12}$ William Gladstone, The Gladstone Diaries, 1848-1854, ed. M.R.D. Foot (Oxford: Clarendon Press, 1968$), 303-304$.

13lbid., 304-308.

${ }^{14}$ Ibid., 310-311.

${ }^{15}$ lbid., 313.

16 lbid., 314.

${ }^{17}$ Ibid., 320-322.

${ }^{18}$ lbid., 322.

${ }^{19}$ William Gladstone, The Gladstone Diaries, 1869-1871, ed. M.R.D. Foot (Oxford: Clarendon Press, 1968$), 204$.

${ }^{20}$ Josef L. Altholz, "Gladstoneand the Vatican Decrees," The Historian 25, no. 3 (1963): 313, http://www.jstor.org/ stable/24441526.

${ }^{21}$ lbid., 314-315.

${ }^{22}$ lbid., 316.

${ }^{23}$ William Gladstone, The Gladstone Diaries, 1871-1874, ed. M.R.D. Foot (Oxford: Clarendon Press, 1968$), 117$.

${ }^{24}$ Ibid., 426.

${ }^{25} J o s e f$ L. Altholz, "Gladstone and the Vatican Decrees," The Historian 25, no. 3 (1963): 313-321, http://www.jstor.org/ stable/24441526. 


\section{Works Cited}

Aldous, Richard. The Lion and the Unicorn. New York, NY: The Random House Group Ltd., 2006.

Altholz, Josef L. "Gladstone and the Vatican Decrees." The Historian 25, no. 3 (1963): 312-324. http://www.jstor.org/ stable/24441526.

Bebbington, David William. William Ewart Gladstone: faith and politics in Victorian Britain. Grand Rapids, MI: W.B. Eerdmans Publishing Co., 1993.

Black, Jeremy and Donald M. Macraild. Nineteenth-Century Britain. New York, NY: Palgrave MacMillan, 2003.

Burnstein, Miriam. "The 'Papal Aggression' Controversy, 1850-52." BRANCH: Britain, Representation, and NineteenthCentury History. N.d. 21 February 2018. http://www.branchcollective.org/?ps_articles=miriam-burstein-thepapal-aggression-controversy-1850-52.

Faught, C. Brad. "Disraeli and Gladstone in the 1840s: The Influence of the Oxford Movement on Young England and the Board of Trade. The Canadian Society of Church History. https://churchhistcan.files.wordpress. com/2013/06/1995-4-faught-article.pdf.

Faught, C. Brad. The Oxford Movement: a thematic history of the tractarians and their times. University Park, PA: Pennsylvania State University Press, 2003.

Gladstone, William. The Gladstone Diaries. ed. M.R.D. Foot. Oxford: Clarendon Press, 1968.

Matthew, H.C. G. "Gladstone, William Ewart." Oxford Dictionary of National Biography. 23 September 2004. https:// doi-org.ezproxy.tcu.edu/10.1093/ref:odnb/10787.

Newman, John Henry. Tract 90. 1841. Project Canterbury. http://anglicanhistory.org/tracts/tract90/fulltext.html.

Norman, Edward R. The English Catholic Church in the nineteenth century. Oxford: Clarendom Press, 1984.

Ralls, Walter. "The Papal Aggression of 1850: A Study in Victorian Anti-Catholicism. Church History 43, no. 2 (1974): 242-256. DOI: 10.2307/3163955. http://www.jstor.org/stable/3163955.

Wallis, Frank H. Popular anti-Catholicism in mid-Victorian Britain. Lewiston, NY: E. Mellen Press, 1993. 